\title{
A Novel Laccase with Potent Antiproliferative and HIV-1 Reverse Transcriptase Inhibitory Activities from Mycelia of Mushroom Coprinus comatus
}

\author{
Shuang Zhao, ${ }^{1}$ Cheng-Bo Rong, ${ }^{1}$ Chang Kong, ${ }^{2}$ Yu Liu, ${ }^{1}$ Feng Xu, ${ }^{1}$ Qian-Jiang Miao, \\ Shou-Xian Wang, ${ }^{1}$ He-Xiang Wang, ${ }^{2}$ and Guo-Qing Zhang ${ }^{3}$ \\ ${ }^{1}$ Institute of Plant and Environment Protection, Beijing Academy of Agriculture and Forestry Sciences, \\ Beijing Engineering Research Center for Edible Mushroom, Beijing 100097, China \\ ${ }^{2}$ State Key Laboratory for Agrobiotechnology and Department of Microbiology, China Agricultural University, Beijing 100193, China \\ ${ }^{3}$ Key Laboratory of Urban Agriculture (North) of Ministry of Agriculture, College of Biological Sciences and Engineering, \\ Beijing University of Agriculture, Beijing 102206, China
}

Correspondence should be addressed to He-Xiang Wang; hxwang@cau.edu.cn and Guo-Qing Zhang; zhanggq1001@gmail.com

Received 4 June 2014; Revised 16 August 2014; Accepted 16 August 2014; Published 28 August 2014

Academic Editor: Isabel Sá-Correia

Copyright (C) 2014 Shuang Zhao et al. This is an open access article distributed under the Creative Commons Attribution License, which permits unrestricted use, distribution, and reproduction in any medium, provided the original work is properly cited.

\begin{abstract}
A novel laccase was isolated and purified from fermentation mycelia of mushroom Coprinus comatus with an isolation procedure including three ion-exchange chromatography steps on DEAE-cellulose, CM-cellulose, and Q-Sepharose and one gel-filtration step by fast protein liquid chromatography on Superdex 75. The purified enzyme was a monomeric protein with a molecular weight of $64 \mathrm{kDa}$. It possessed a unique $\mathrm{N}$-terminal amino acid sequence of AIGPVADLKV, which has considerably high sequence similarity with that of other fungal laccases, but is different from that of $C$. comatus laccases reported. The enzyme manifested an optimal $\mathrm{pH}$ value of 2.0 and an optimal temperature of $60^{\circ} \mathrm{C}$ using $2,2^{\prime}$-azinobis(3-ethylbenzothiazolone-6-sulfonic acid) diammonium salt (ABTS) as the substrate. The laccase displayed, at $\mathrm{pH} 2.0$ and $37^{\circ} \mathrm{C}, K_{m}$ values of $1.59 \mathrm{mM}$ towards ABTS. It potently suppressed proliferation of tumor cell lines HepG2 and MCF7, and inhibited human immunodeficiency virus type 1 (HIV1) reverse transcriptase (RT) with an $\mathrm{IC}_{50}$ value of $3.46 \mu \mathrm{M}, 4.95 \mu \mathrm{M}$, and $5.85 \mu \mathrm{M}$, respectively, signifying that it is an antipathogenic protein.
\end{abstract}

\section{Introduction}

Laccases (benzenediol:oxygen oxidoreductase; EC 1.10.3.2), belonging to polyphenol oxidases, play a key role in lignin degradation in nature. They can oxidate a variety of phenolic and inorganic compounds, including diphenols, polyphenols, and substituted phenols, using molecular oxygen as the electron acceptor [1,2]. Although they were first reported and named from plant, laccases are widely distributed in higher plants and fungi and have also been found in insects and bacteria [3]. Laccases are involved in various physiological roles in nature. Botanical laccases contribute to lignin synthesis, while fungal laccases are conversely involved in lignin degradation and also pathogenesis $[3,4]$. In recent years, the occurrence and properties of the laccases have been comprehensively reviewed due to their potential uses in lignin biodegradation, synthetic dye decolorization, paperpulp bleaching, bioremediation, biosensors, chemical synthesis, and so forth $[2,5]$.

Coprinus comatus, commonly named as lawyer's wig or shaggy mane, is a common fungus often seen growing on lawns in spring or autumn. In China, Japan, and other Asian countries, the species is cultivated as an excellent edible mushroom. It is very unusual because it is edible when young but becomes poisonous when old. The cap is white and closely covers the stipe over; then it turns black and dissolves itself in a matter of hours after being picked or depositing spores. Previous studies on C. comatus 
mainly focus on its polysaccharide extract, antitumor and immunomodulatory activities, fermentation, and so forth. In recent researches, ethyl acetate extract from fruit bodies of $C$. comatus manifested antiproliferative activity towards human ovarian cancer cell lines [6]. A water-soluble polysaccharide demonstrated inhibitory activity towards Sarcoma 180 tumor cell in mice. It can significantly enhance the Con A- or LPSinduced splenocyte proliferation and increase the production of TNF- $\alpha$ and IL-2 [7]. Vanadium-enriched C. comatus promoted femoral fracture healing in streptozotocin-diabetic rats with a $35.5 \%$ increase in the total area of callus [8]. There are only few literatures about bioactive proteins from $C$. comatus. A fibrin-specific fibrinolytic enzyme was produced by liquid culture of C. comatus [9]. Recently, Bao et al. cloned a laccase isoenzyme gene from C. comatus, and functionally heterologously expressed it in Pichia pastoris [10].

In the present work, preliminary studies based on mycelia of $C$. comatus showed that laccase extract demonstrated different enzymatic properties from those of the recombinant laccase newly reported [10]. Hence, we aim to purify the laccase from $C$. comatus and then study its properties and applications.

\section{Materials and Methods}

2.1. Strain and Culture Condition. Fruiting bodies of $C$. comatus were collected in the campus of China Agricultural University (Beijing, China). Strain JT-01 was isolated from fresh fruiting bodies. Strain identification was based on a standard ITS sequence amplification and analysis and also fruiting experiments [11]. The fungus was cultured at $26^{\circ} \mathrm{C}$, stored at $4^{\circ} \mathrm{C}$, and monthly transferred to fresh PDA slants which contained (g/L) potato, 200; glucose, 20; and agar, 20. For purification of the laccase, strain JT-01 was inoculated into the liquid PD media which contained (g/L) potato, 200, and glucose, 20. The media were cultured using an orbital shaking incubator at $200 \mathrm{rpm}$ and $26^{\circ} \mathrm{C}$ for 2 weeks. Then, the mycelia were collected for further laccase purification.

2.2. Assay for Laccase Activity. Laccase activity was determined by a modified method described by Shin and Lee using 2,2' -azinobis(3-ethylbenzothiazolone-6-sulfonic acid) diammonium salt (ABTS) as the substrate [12]. In brief, enzyme solution $(5 \mu \mathrm{L})$ was mixed with $1 \mathrm{mM}$ ABTS solution $(145 \mu \mathrm{L}$, in $50 \mathrm{mM}$ sodium acetate buffer, $\mathrm{pH} 4.5)$ at $37^{\circ} \mathrm{C}$ for $5 \mathrm{~min}$, followed by ending the reaction by an addition of $10 \%$ TCA $(250 \mu \mathrm{L})$. The change in the absorbance was monitored at $405 \mathrm{~nm}$ for enzyme activity. One enzyme unit (U) was defined as the amount of enzyme required to produce one absorbance increase at $405 \mathrm{~nm}$ per minute per millilitre of the reaction mixture under the assay conditions. All determinations were performed in triplicate.

2.3. Purification of Laccase. After two-week fermentation, mycelia were harvested by centrifugation at $10000 \mathrm{rpm}$ and $4^{\circ} \mathrm{C}$ for $15 \mathrm{~min}$. Subsequently, the mycelia homogenized and extracted in $0.15 \mathrm{M} \mathrm{NaCl}(1: 4, \mathrm{w} / \mathrm{v})$ at $4^{\circ} \mathrm{C}$ overnight, followed by another centrifugation at $10000 \mathrm{rpm}$ and $4^{\circ} \mathrm{C}$ for $15 \mathrm{~min}$.
Then, $\left(\mathrm{NH}_{4}\right)_{2} \mathrm{SO}_{4}$ was added to the supernatant until $80 \%$ saturation to precipitate proteins. The mixture was left $4^{\circ} \mathrm{C}$ for $4 \mathrm{~h}$, then centrifuged at $10000 \mathrm{rpm}$ and $4^{\circ} \mathrm{C}$ for $15 \mathrm{~min}$, and dialyzed against distilled water overnight. The crude laccase extract was further purified by three successive steps of ion exchange chromatography: firstly on DEAE-cellulose $(10 \mathrm{mM}$ phosphate buffer, $\mathrm{pH} 7.0$ ) with a flow rate of $2 \mathrm{~mL} / \mathrm{min}$, secondly on CM-cellulose (10 mM phosphate buffer, $\mathrm{pH}$ 6.6) with a flow rate of $2 \mathrm{~mL} / \mathrm{min}$, and finally on Q-Sepharose (10 mM sodium acetate buffer, $\mathrm{pH} 4.0$ ) with a flow rate of $1 \mathrm{~mL} / \mathrm{min}$. The laccase active fraction was finally purified by fast protein liquid chromatography (FPLC) on a Superdex 75 HR 10/30 gel filtration column $\left(0.2 \mathrm{M} \mathrm{NH}_{4} \mathrm{HCO}_{3}\right.$ buffer, $\mathrm{pH}$ 8.5 ) with a flow rate of $0.8 \mathrm{~mL} / \mathrm{min}$.

2.4. Determination of Molecular Mass. To determine the molecular mass $(M r)$ of the purified laccase, both FPLCgel filtration and sodium dodecyl sulfate-polyacrylamide gel electrophoresis (SDS-PAGE) were used. In FPLC-gel filtration, a standard curve based on elution volume and $\mathrm{Mr}$ of molecular mass standards (GE Healthcare) can be obtained. $\mathrm{Mr}$ of the present laccase fraction can be calculated [15]. In SDS-PAGE, a $12 \%$ resolving gel and a 5\% stacking gel were used following procedure of Laemmli and Favre [16]. The $\mathrm{Mr}$ was calculated based on another curve of relative mobility and $\log M r$.

2.5. Determination of N-Terminal Amino Acid Sequence. The $\mathrm{N}$-terminal amino acid sequence of the purified laccase was determined using a Hewlett-Packard HP G1000A Edman degradation unit and an HP 1000 HPLC System [17].

2.6. Effect of $p H$ and Temperature on Laccase Activity. In the $\mathrm{pH}$ assay, a series ABTS solution in different $\mathrm{pH}$ value was used instead of the ABTS solution at $\mathrm{pH} 4.5$ in the standard enzyme assay. The assay buffers were prepared in $\mathrm{KCl}-\mathrm{HCl}$ buffers ( $\mathrm{pH}$ 1.1-2.2) and sodium citrate acid buffers ( $\mathrm{pH} 2.2-$ 8.0 ). In the temperature assay, standard assay mixture was tested in different temperature $\left(20-100^{\circ} \mathrm{C}\right)$ instead of $37^{\circ} \mathrm{C}$ in the standard assay.

2.7. Assay for Enzyme Kinetic of Purified Laccase. The Michaelis-Menten constants of the purified laccase were determined using ABTS as substrate at $\mathrm{pH} 2.0$ in various concentrations $(0.5,1.0,1.5,2.0,3.0,4.0$, and $5.0 \mathrm{mM})$ and at $37^{\circ} \mathrm{C}$. All determinations were performed in triplicate. The $\mathrm{Km}$ values were obtained from a Lineweaver-Burk plot [24].

2.8. Effect of Metal Ions and EDTA on Laccase Activity. To estimate metal ions and EDTA on enzyme activity, equal volumes of the purified laccase solution were preincubated with metal ions or EDTA solutions (at concentrations of $2.5,5.0,10$, and $20 \mathrm{mM}$, resp.) at $4^{\circ} \mathrm{C}$ for $1 \mathrm{~h}$ before the standard laccase assay was performed. The chemical reagents of metal ions were including $\mathrm{AlCl}_{3}, \mathrm{CaCl}_{2}, \mathrm{CoCl}_{2}, \mathrm{CuCl}_{2}$, $\mathrm{FeCl}_{2}, \mathrm{HgCl}_{2}, \mathrm{KCl}, \mathrm{LiCl}, \mathrm{MgCl}_{2}, \mathrm{MnCl}_{2}, \mathrm{ZnCl}_{2}$, and EDTA. Control samples were assayed without the metal ions. All determinations were performed in triplicate. 
TABLE 1: Yields and laccase activities of various chromatographic fractions (from 50 g mycelia).

\begin{tabular}{|c|c|c|c|c|c|}
\hline Fraction & Yield (mg) & $\begin{array}{l}\text { Total activity } \\
(\mathrm{U})\end{array}$ & $\begin{array}{c}\text { Specific activity } \\
(\mathrm{U} / \mathrm{mg})\end{array}$ & $\begin{array}{l}\text { Recovery of } \\
\text { activity (\%) }\end{array}$ & Purification fold \\
\hline $\begin{array}{l}80 \% \text { ammonium } \\
\text { sulphate fractionation }\end{array}$ & 996 & 13814.42 & 13.86 & 100 & 1 \\
\hline D1 & 104.18 & - & - & - & - \\
\hline D2 & 85.89 & - & - & - & - \\
\hline D3 & 35.31 & 3357.96 & 95.09 & 24.3 & 6.9 \\
\hline D4 & 436.16 & - & - & - & - \\
\hline $\mathrm{C} 1$ & 20.62 & - & - & - & - \\
\hline $\mathrm{C} 2$ & 14.67 & - & - & - & - \\
\hline $\mathrm{C} 3$ & 3.234 & 2091.72 & 646.79 & 15.1 & 46.6 \\
\hline $\mathrm{C} 4$ & 2.28 & - & - & - & - \\
\hline Q1 & 1.76 & - & - & - & - \\
\hline Q2 & 1.85 & 1334.11 & 721.14 & 9.7 & 52 \\
\hline SU1 & 1.48 & 1078.97 & 729.04 & 7.8 & 52.6 \\
\hline SU2 & 0.35 & - & - & - & - \\
\hline
\end{tabular}

-: no laccase activity observed. Laccase-enriched fractions were highlighted in boldface.

2.9. Assay of Antiproliferative Activity. Antiproliferative activity has been reported for many mushroom proteins [25]. The tumor cell lines human breast cancer (MCF7) and hepatoma (HepG2) were purchased from American Type Culture Collection (ATCC). HepG2 cells were cultured in Dulbecco modified Eagle's medium (DMEM), and MCF7 cells were cultured in RPMI medium supplemented with $10 \%$ (v/v) fetal bovine serum (FBS), $100 \mathrm{mg} / \mathrm{l}$ streptomycin, and $100 \mathrm{IU} / \mathrm{mL}$ penicillin at $37^{\circ} \mathrm{C}$ in a humidified atmosphere of $5 \%(\mathrm{v} / \mathrm{v}) \mathrm{CO}_{2}$. Cells were seeded into 96-well plates with a concentration of $8 \times 10^{3}$ cells/well and incubated for $24 \mathrm{~h}$. Different concentrations of $C$. comatus laccase were added into the wells with serum-free medium and incubated for $72 \mathrm{~h}$. After that, MTT assays were carried out to measure cell viability. Briefly, $20 \mu \mathrm{L}$ of a $5 \mathrm{mg} / \mathrm{mL}$ solution of MTT in serum-free medium was spiked into each well, and the plates were incubated for $4 \mathrm{~h}$. The supernatant was carefully removed, and $200 \mu \mathrm{L}$ of DMSO was added into each well to dissolve the MTT formazan. The absorbance at $560 \mathrm{~nm}$ was measured with a microplate reader. PBS was added into the wells instead of laccase as the control $[11,26]$.

2.10. Assay for HIV-1 Reverse Transcriptase Inhibitory Activity. The assay for the inhibitory activity on human immunodeficiency virus type 1 (HIV-1) reverse transcriptase (RT) was assessed using an enzyme-linked immunosorbent assay (ELISA) kit from Boehringer (Mannheim, Germany) [27]. The assay takes advantage of the ability of reverse transcriptase to synthesize DNA, starting from the template primer hybrid poly(A) oligo(dT)15. An optimized ratio of the digoxigenin- and biotin-labeled nucleotides is incorporated into one of the DNA molecules synthesized by the RT. The detection and quantification of synthesized DNA as a parameter for RT activity follow the sandwich ELISA protocol. Biotin-labeled DNA binds to the surface of microtiter plate modules precoated with streptavidin. An antibody to digoxigenin conjugated to peroxidase (anti-DIG-POD) binds to the digoxigenin-labeled DNA. Finally, the peroxidase substrate is added. The peroxidase enzyme catalyzes the cleavage of the substrate and produces a colored reaction product. The absorbance of the samples at $405 \mathrm{~nm}$ can be determined by using a microtiter plate (ELISA) reader and is directly correlated with the level of RT activity. A fixed amount (4-6 ng) of recombinant HIV-1 RT was used. The inhibitory activity of the laccase was calculated as percent inhibition compared to a control without the protein.

\section{Results}

3.1. Laccase Purification and Molecular Mass Determination. The laccase was highly purified from the cultured mycelial extract by employing initial ammonium sulfate precipitation and centrifugation steps, followed by three ion-exchange chromatography steps on DEAE-cellulose, CM-cellulose, and Q-Sepharose and a final gel-filtration step by fast protein liquid chromatography on Superdex 75. The yields and specific laccase activities at various stages of purification are listed in Table 1. An overall 52.6-fold purification was achieved with an activity recovery of $7.8 \%$. The crude enzyme extract was chromatographed on DEAE-cellulose into four fractions: D1, D2, D3, and D4 after elution with 0, 100, 200, and $1000 \mathrm{mM} \mathrm{NaCl}$, respectively, in phosphate buffer $(10 \mathrm{mM}$, $\mathrm{pH}$ 7.0) (Figure 1(a)). The fraction D3 with laccase activity was subsequently applied to CM-cellulose and eluted with phosphate buffer $(10 \mathrm{mM}, \mathrm{pH} 6.6)$. It was also separated into four fractions C1, C2, C3, and C4 with 0, 100, 150, and $1000 \mathrm{mM}$ $\mathrm{NaCl}$ in the same buffers, respectively (Figure 1(b)). Fraction C3 containing laccase activity was further fractionated to QSepharose and eluted with a linear gradient of $0-150 \mathrm{mM}$ $\mathrm{NaCl}$ in sodium acetate buffer ( $\mathrm{pH} 4.0)$. It was divided into an unabsorbed fraction Q1 with no laccase activity and a larger absorbed fraction Q2 with high laccase activity (Figure 1(c)). 
TABLE 2: Comparison of partial amino acid sequence of C. comatus laccase (CCL) in this study and other laccase or laccase-like proteins from C. comatus earlier reported.

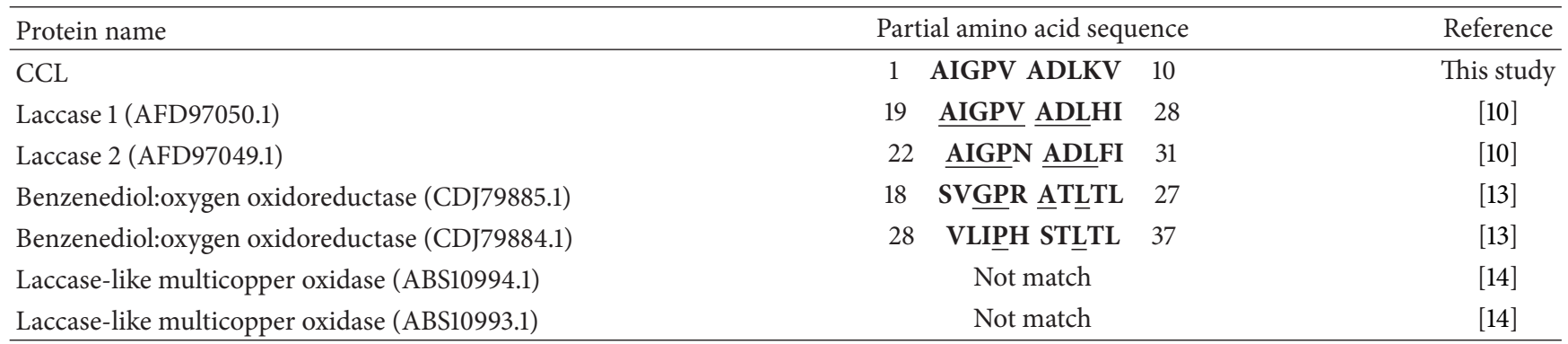

Amino acid residues identical to the corresponding residues of the purified laccase are underlined.

Finally, fraction Q2 was resolved into two peaks with gel filtration on Superdex 75 (Figure 1(d)). Laccase activity was concentrated in fraction SU1 with a molecular mass $(M r)$ of $64 \mathrm{kDa}$. In SDS-PAGE, SU1 fraction appeared as a single band with a $M r$ of $64 \mathrm{kDa}$ (Figure 2). This suggested that the native laccase is a monomeric protein.

3.2. Properties of Purified Laccase. The N-terminal amino acid sequence of $C$. comatus laccase (CCL) is AIGPVADLKV. An N-terminal amino acid sequence comparison of CCL in the present study and other laccases or laccase-like proteins from C. comatus earlier reported was listed in Table 2. Another comparison of CCL and other fungal laccases in their N-terminal amino acid sequences was presented in Table 3. The purified laccase expressed its maximal oxidizing activity towards ABTS at pH 2.0 (Figure 3(a)). It underwent a sharp increase and a continuous decrease in enzyme activity as assayed in $\mathrm{pH}$ 1.1-8.0. The purified enzyme possessed a considerable high optimal temperature of $60^{\circ} \mathrm{C}$. Oxidizing activity towards ABTS at $60^{\circ} \mathrm{C}$ was twice as high as that at $20^{\circ} \mathrm{C}$ and about 1.2 times as high as that at $40^{\circ} \mathrm{C}$ and $80^{\circ} \mathrm{C}$. More than $10 \%$ of total enzyme activity remained when it was assayed at $100^{\circ} \mathrm{C}$ (Figure 3(b)). After incubation of the purified laccase with various ABTS concentrations (0.5$5.0 \mathrm{mM}$ ), the reactions are found to follow Michaelis-Menten kinetics, displaying the $K m$ value of $1.59 \mathrm{mM}$ towards ABTS using Lineweaver-Burk plots (Figure 4). The sensitivity of CCL to metal ions and EDTA is shown in Table 4. The purified enzyme activity is not significantly affected by the presence of EDTA at an assay concentration range of 1.25$10 \mathrm{mM}, \mathrm{K}^{+}$, and $\mathrm{Co}^{2+}$ at the assay concentration range of 1.25$5.0 \mathrm{mM}, \mathrm{Cu}^{2+}, \mathrm{Mn}^{2+}$, and $\mathrm{Zn}^{2+}$ at the assay concentration range of $1.25-2.5 \mathrm{mM}$. $\mathrm{Cu}^{2+}$ can slightly enhance the enzyme activity of about $10 \%$ when the assay concentration reached 5.0-10 mM. On the contrary, CCL activity was continuously reduced by $\mathrm{Fe}^{2+}, \mathrm{Hg}^{2+}, \mathrm{Ca}^{2+}, \mathrm{Mn}^{2+}, \mathrm{Li}^{+}$, and $\mathrm{Al}^{3+}$ when the ion concentration rises from $1.25 \mathrm{mM}$ to $10 \mathrm{mM}$.

Antiproliferative activity towards tumor cell lines and inhibitory activity towards HIV-1 RT were determined using $\mathrm{IC}_{50}$ value which is the concentration of IBL that results in an inhibition ratio of $50 \%$. The purified laccase demonstrates antiproliferative activity towards tumor cell lines HepG2 and MCF7 and inhibitory activity towards HIV-1 RT with
IC $_{50}$ values of $3.46 \mu \mathrm{M}, 4.95 \mu \mathrm{M}$, and $5.85 \mu \mathrm{M}$, respectively (Figure 5).

\section{Discussion}

The shaggy mane mushroom is a common but unusual mushroom species because it is widely distributed but will turn black and dissolve itself in a matter of hours after maturation. Up to now, only 6 protein sequences from C. comatus have been reported (EMB or GenBank Accession numbers CDJ79885.1, CDJ79884.1, AFD97050.1, AFD97049.1, ABS10994.1, and ABS10993.1) [13]. The present laccase possesses considerably high sequence similarity with those $C$. comatus laccases or laccase-like proteins reported, but they are obviously different with the highest similarity of $80 \%$. It suggests that the purified laccase in the present study is a novel laccase among those C. comatus laccases reported. On the other hand, CCL also manifests considerable similarity with other Polyporaceae laccases at the $\mathrm{N}$ terminal position, which suggests that they might share a similar protein secondary or tertiary structure.

During the purification process, CCL was absorbed on DEAE-cellulose, CM-cellulose, and Q-Sepharose, just like other fungal laccases from Agrocybe cylindracea [17], Russula virescens [28], and Pleurotus eryngii [29]. On the other hand, a newly reported laccase from Lepiota ventriosospora is unabsorbed on CM-cellulose [30]. The purification factor and yield are related to elution procedure. CCL manifests a purification factor of 52.6-fold, which is considerably higher than that of Clitocybe maxima (16.8-fold) [27] and the monkey head mushroom Hericium erinaceus (15-fold) [31]. During the purification of C. maxima laccase, SP-Sepharose, a kind of strong cation chromatography media, was used instead of CM-cellulose. Parts of laccase active fraction might be irreversibly adsorbed on the gel. On the other hand, when the $H$. erinaceum laccase was purified, four successive steps of ion exchange chromatography and one gel filtration were used. The more the purification steps were used, the less the objective proteins were gained.

The present laccase is a monomeric protein with a molecular mass of $64 \mathrm{kDa}$, which falls well within the range of molecular masses for most of the fungal laccases reported $(50-90 \mathrm{kDa})[3]$. It is just the same as that of laccase from Pleurotus nebrodensis $(64 \mathrm{kDa})$ [32]. that of laccases from 


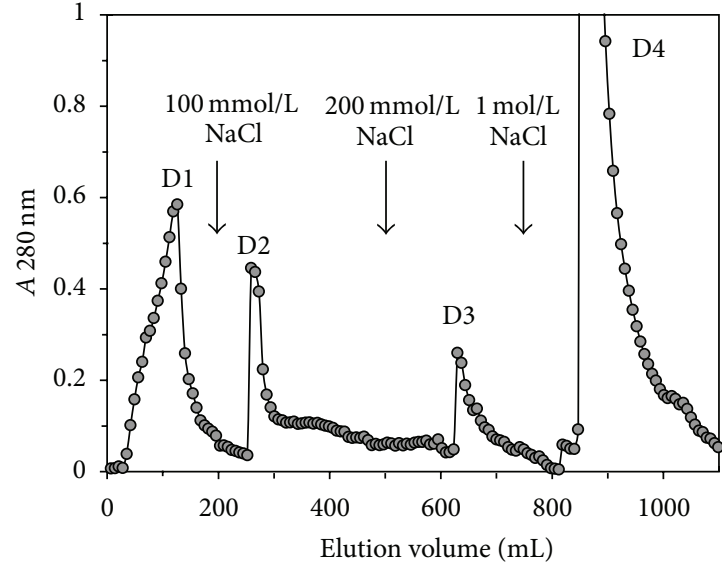

(a)

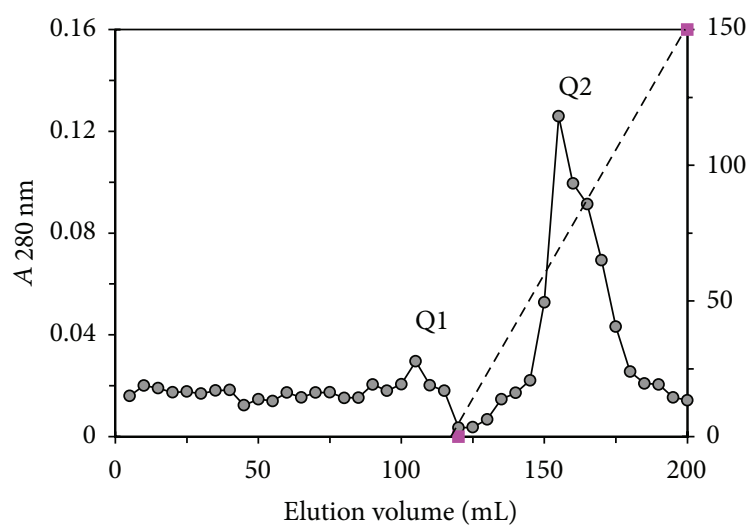

(c)

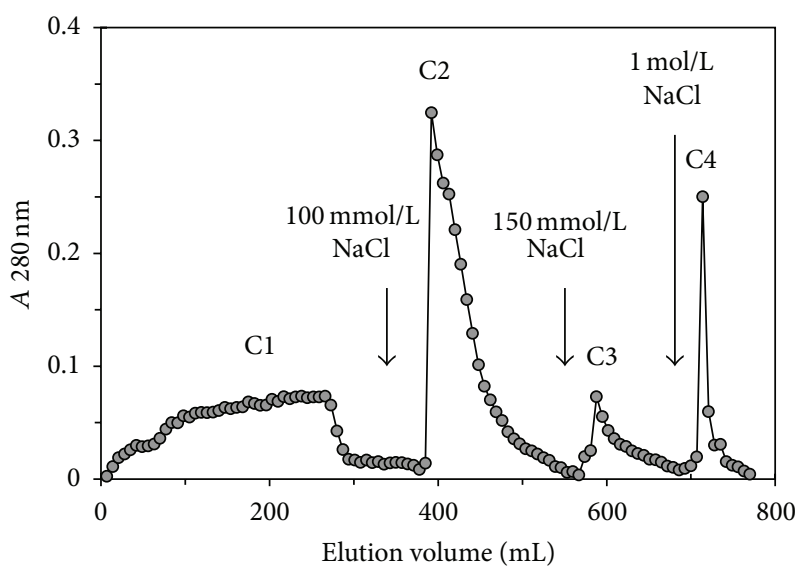

(b)

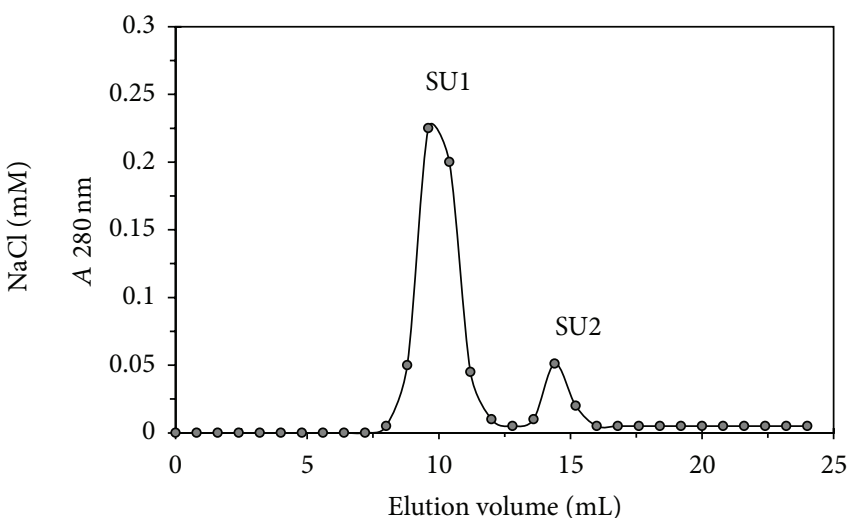

(d)

FIGURE 1: Elution profiles of C. comatus laccase. (a) Ion exchange chromatography on DEAE-cellulose column. Fraction D3 was the laccase concentrated fraction. (b) Ion exchange chromatography on CM-cellulose column. Fraction C3 was the laccase concentrated fraction. (c) Ion exchange chromatography on Q-Sepharose column. Fraction Q2 was the laccase concentrated fraction. (d) Gel filtration on Superdex 75. Fraction SU1 was purified laccase.

TABLE 3: Comparison of the N-terminal sequence of C. comatus laccase (CCL) with other fungal laccases.

\begin{tabular}{lcc}
\hline Fungal laccase & N-terminal sequence & Reference \\
\hline $\begin{array}{l}\text { Coprinus comatus laccase (CCL) } \\
\text { Pycnoporus cinnabarinus laccase }\end{array}$ & AIGPVADLKVI & This study \\
Trametes versicolor laccase I & $\underline{\text { AIGPVADLTL }}$ & {$[18]$} \\
Trametes versicolor laccase II & $\underline{\text { AIGPVASLVV }}$ & {$[19]$} \\
Basidiomycete PM1 laccase & GIGPVADLTI & {$[19]$} \\
Trametes versicolor laccase III & SIGPVADLTI & {$[20]$} \\
Coriolus hirsutus laccase & GIGPVADLTI & {$[12]$} \\
Inonotus baumii laccase & $\underline{\text { AIGPTADLTI }}$ & {$[21]$} \\
Ceriporiopsis subvermispora laccase & $\underline{\text { AIGPVDEV }}$ & {$[11]$} \\
Pleurotus ostreatus laccase & $\underline{\text { AIGPVTDLEI }}$ & {$[22]$} \\
\hline
\end{tabular}

Amino acid residues identical to the corresponding residues of the purified laccase are underlined.

Pleurotus nebrodensis (64 kDa) [32], H. echinaceus (63 kDa) [31]. Just like most of the fungal laccases, C. comatus laccase is a monomeric protein, while laccases from Phellinus ribis and Gaeumannomyces graminis are dimeric and quadruple proteins, respectively $[34,35]$.
The purified laccase manifests a quite low $\mathrm{pH}$ optimum of $\mathrm{pH} 2.0$ towards ABTS, which is much lower than that of laccases from A. cylindracea ( $\mathrm{pH}$ 5.2) [17], P. nebrodensis ( $\mathrm{pH}$ 5.0) [32], and L. ventriosospora ( $\mathrm{pH} 4.0$ ) [30]. Laccases from A. blazei ( $\mathrm{pH} 2.3$ ) and $R$. virescens ( $\mathrm{pH} 2.2$ ) also share a 


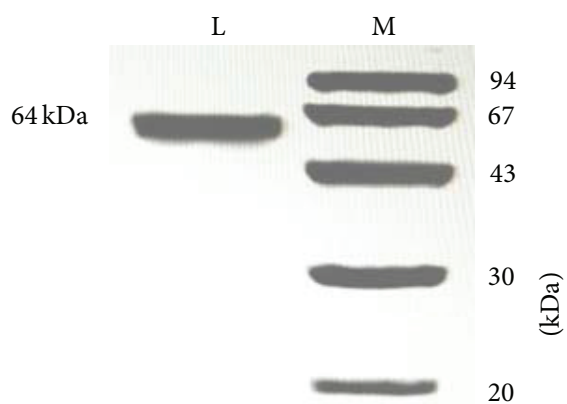

14.4

FIGURE 2: SDS-PAGE of C. comatus laccase (fraction SU1). Left lane: C. comatus laccase. Right lane: molecular mass markers. From top downward: phosphorylase b $(94 \mathrm{kD})$, bovine serum albumin $(67 \mathrm{kD})$, ovalbumin $(43 \mathrm{kD})$, carbonic anhydrase $(30 \mathrm{kD})$, soybean trypsin inhibitor $(20 \mathrm{kD})$, and lactalbumin $(14.4 \mathrm{kD})$.

TABle 4: Effect of metal ions and EDTA on C. comatus laccase activity.

\begin{tabular}{lcccc}
\hline \multirow{2}{*}{ Metal ions } & \multicolumn{4}{c}{ Residual activity (\% of control) } \\
& $1.25 \mathrm{mM}$ & $2.5 \mathrm{mM}$ & $5 \mathrm{mM}$ & $10 \mathrm{mM}$ \\
\hline $\mathrm{Al}^{3+}$ & 89.1 & 88.5 & 85.4 & 84.3 \\
$\mathrm{Ca}^{2+}$ & 86.0 & 83.8 & 80.6 & 69.7 \\
$\mathrm{Co}^{2+}$ & 100 & 100 & 100.9 & 89.9 \\
$\mathrm{Cu}^{2+}$ & 98.0 & 100 & 110.8 & 110.4 \\
$\mathrm{Fe}^{2+}$ & 34.2 & 28.1 & 22.1 & 10.7 \\
$\mathrm{Hg}^{2+}$ & 82.3 & 71.2 & 61.8 & 45.5 \\
$\mathrm{~K}^{+}$ & 98.0 & 106.4 & 97.8 & 91.0 \\
$\mathrm{Li}^{+}$ & 85.3 & 86.8 & 87.4 & 83.0 \\
$\mathrm{Mg}^{2+}$ & 99.7 & 100 & 86.8 & 80.9 \\
$\mathrm{Mn}^{2+}$ & 94.1 & 91.1 & 85.8 & 70.0 \\
$\mathrm{Zn}^{2+}$ & 100 & 98.9 & 90.0 & 88.0 \\
EDTA & 98.9 & 100 & 98.0 & 97.5 \\
\hline
\end{tabular}

Laccase activity in the absence of metal ions was regarded as $100 \%$.

very low $\mathrm{pH}$ optimum, while laccase from Pleurotus ostreatus reaches its maximal oxidizing activity towards $\mathrm{ABTS}$ at $\mathrm{pH}$ 6.9 which is very close to neutral [23]. The present laccase possesses a considerable high optimal temperature of $60^{\circ} \mathrm{C}$, just the same as that of laccases from $R$. virescens [28], twice as that of laccase from A. placomyces $\left(30^{\circ} \mathrm{C}\right)[17]$, and three times as that of laccase from the sanghuang mushroom Inonotus baumii $\left(20^{\circ} \mathrm{C}\right)$ [11]. It suggests that CCL manifests a potential application at low $\mathrm{pH}$ and high temperature conditions.

The $K m$ value of the purified laccase towards ABTS at $\mathrm{pH}$ 2.0 and $37^{\circ} \mathrm{C}$ was $1.59 \mathrm{mM}$ which was 10 times higher than that of $R$. virescens laccase $(0.115 \mathrm{mM})$ [28]. A recombinant expressed C. comatus laccase (Lacl) manifested a much lower $\mathrm{Km}$ value towards ABTS of $34 \mu \mathrm{M}$ at its optimal enzymatic conditions $\left(\mathrm{pH} 3.0\right.$ and $\left.65^{\circ} \mathrm{C}\right)$ [10]. In the present study, the $\mathrm{Km}$ value was assayed at a lower temperature of $37^{\circ} \mathrm{C}$

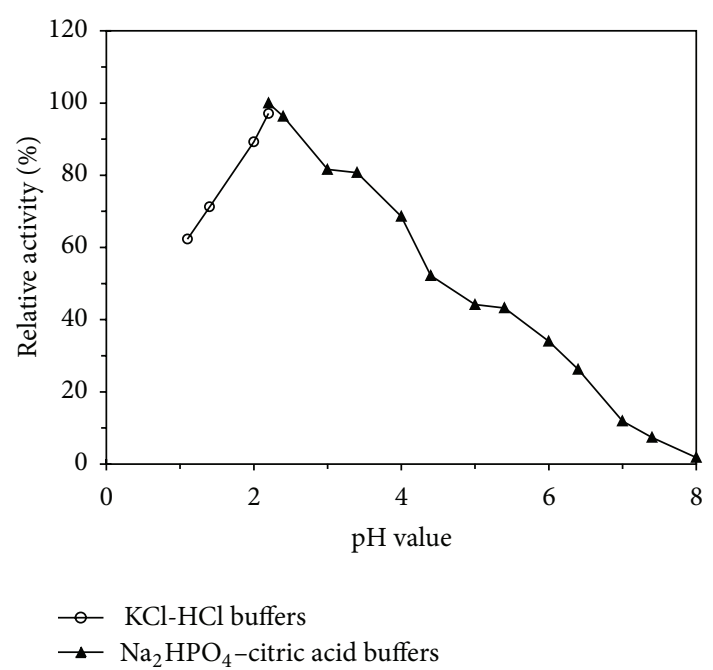

(a)

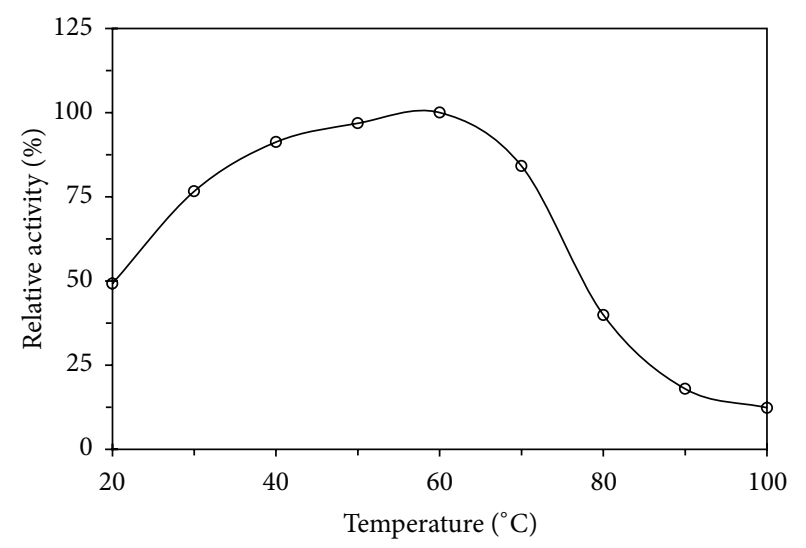

(b)

FIgure 3: Optimal pH and temperature of C. comatus laccase. (a) $\mathrm{pH}$ optimum of the purified laccase. Laccase activity was assayed towards ABTS ( $\mathrm{pH} \mathrm{1.1-8.0)}$ at $37^{\circ} \mathrm{C}$. (b) Temperature optimum of the purified laccase. Assay solution was assayed at $20-100^{\circ} \mathrm{C}$ instead of $37^{\circ} \mathrm{C}$ in the standard enzyme assay.

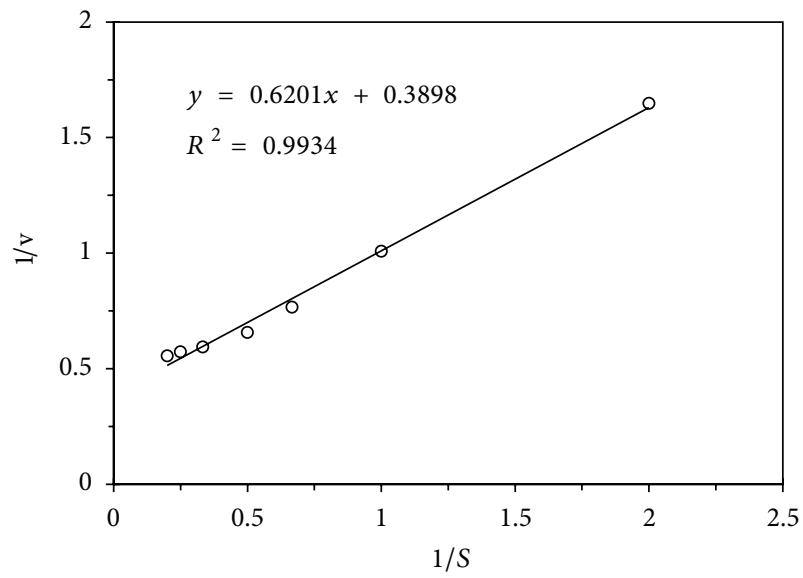

FIgURE 4: Determination of the kinetics parameter of purified $C$. comatus laccase towards ABTS using Lineweaver-Burk plot. 


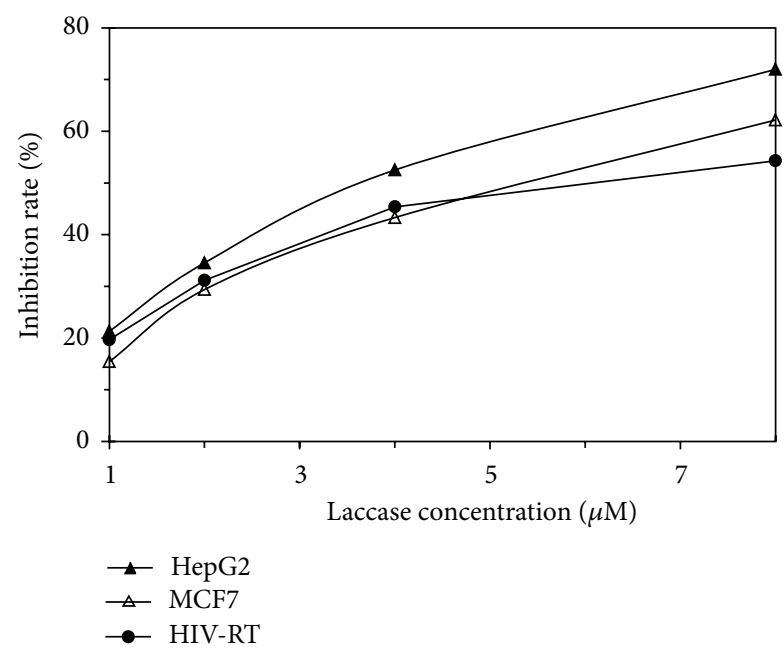

FIGURE 5: Inhibitory activities of C. comatus laccase against HepG2, MCF7, and HIV-1 reverse transcriptase.

but not its optimal temperature of $60^{\circ} \mathrm{C}$. That is why $\mathrm{Km}$ of CCL was much higher than that of Lacl. The present laccase was not sensitive to the assayed metal ions and EDTA except $\mathrm{Fe}^{2+} . \mathrm{Fe}^{2+}$ is a reducing agent and strongly decreases most of the reported laccases, such as Lacl from C. comatus [10] and other fungal laccases from Abortiporus biennis [36], I. baumii [11], and $R$. virescens [28]. $\mathrm{Cu}^{2+}$ was a special ion for the laccase activity. High concentration of $\mathrm{Cu}^{2+}(5-$ $10 \mathrm{mM}$ ) slightly increased the laccase activity just like that of laccases for Polyporus sp. [37] and A. biennis [36]. CCL is not significantly affected by the presence of EDTA (1.25$10 \mathrm{mM}$ ). It is suggested that the core metal ions were stable at the concentration.

It is remarkable that some of mushroom components including laccases, lectins, polysaccharopeptides, and antifungal proteins exhibit inhibitory activities towards tumor cells or HIV-1 RT. In the present study, CCL manifests both antiproliferative and anti-HIV-1 RT activities with an $\mathrm{IC}_{50}$ value towards HepG2, MCF7, and HIV-1 RT of $3.46 \mu \mathrm{M}$, $4.95 \mu \mathrm{M}$, and $5.85 \mu \mathrm{M}$, respectively, indicating that it is also an antipathogenic protein. The laccase from I. baumii, a very famous traditional Chinese medicinal mushroom, also manifests antiproliferative activities towards tumor cell lines HepG2 and L1210 with $\mathrm{IC}_{50}$ values of $2.4 \mu \mathrm{M}$ and $3.2 \mu \mathrm{M}$, respectively, but is devoid of inhibitory activity toward HIV1 RT. On the other hand, the present laccase is purified from liquid fermentation, which means that the protein is very easy to obtain. It is noteworthy that it possesses further applications of agents for cancer or AIDS therapy.

\section{Conclusions}

In summary, a novel laccase (CCL) with a distinctive $\mathrm{N}$ terminal sequence is purified from mycelia of mushroom $C$. comatus obtained from liquid fermentation. Characterization studies show that the enzyme possesses a molecular mass of $64 \mathrm{kDa}$, a $\mathrm{pH}$ optimum at 2.0, a temperature optimum at $60^{\circ} \mathrm{C}$, and a $K_{m}$ value of $1.59 \mathrm{mM}$ towards ABTS. The laccase also exhibits antiproliferative activity towards tumor cells and inhibitory activity toward HIV-1RT, suggesting that it is an antipathogenic protein.

\section{Conflict of Interests}

The authors declare that they have no conflict of interests regarding the publication of this paper.

\section{Acknowledgments}

This work was financially supported by National Grants of China (31200070), Grants from Beijing Academy of Agriculture and Forestry Science (KJCX20140204 and KJCX20140102), and Beijing Higher Education Young Elite Teacher Project (YETP1714).

\section{References}

[1] A. A. Leontievsky, T. Vares, P. Lankinen et al., "Blue and yellow laccases of ligninolytic fungi," FEMS Microbiology Letters, vol. 156, no. 1, pp. 9-14, 1997.

[2] K. Brijwani, A. Rigdon, and P. V. Vadlani, "Fungal laccases: Production, function, and applications in food processing," Enzyme Research, vol. 2010, Article ID 149748, 10 pages, 2010.

[3] P. Baldrian, "Fungal laccases-occurrence and properties," FEMS Microbiology Reviews, vol. 30, no. 2, pp. 215-242, 2006.

[4] U. N. Dwivedi, P. Singh, V. P. Pandey, and A. Kumar, "Structurefunction relationship among bacterial, fungal and plant laccases," Journal of Molecular Catalysis B: Enzymatic, vol. 68, no. 2, pp. 117-128, 2011.

[5] A. M. Mayer and R. C. Staples, "Laccase: new functions for an old enzyme," Phytochemistry, vol. 60, no. 6, pp. 551-565, 2002.

[6] A. Rouhana-Toubi, S. P. Wasser, A. Agbarya, and F. Fares, "Inhibitory effect of ethyl acetate extract of the shaggy inc cap medicinal mushroom, Coprinus comatus (Higher Basidiomycetes) fruit bodies on cell growth of human ovarian cancer," International Journal of Medicinal Mushrooms, vol. 15, no. 5, pp. 457-470, 2013.

[7] X. G. Jiang, M. X. Lian, Y. Han, and S. M. Lv, "Antitumor and immunomodulatory activity of a polysaccharide from fungus Coprinus comatus (Mull.:Fr.) Gray," International Journal of Biological Macromolecules, vol. 58, pp. 349-353, 2013.

[8] G. Wang, J. Wang, Y. Fu et al., "Systemic treatment with vanadium absorbed by Coprinus comatus promotes femoral fracture healing in streptozotocin-diabetic rats," Biological Trace Element Research, vol. 151, no. 3, pp. 424-433, 2013.

[9] X. Liu, X. Zheng, and J.-K. Zhang, "Production of a fibrinolytic enzyme from coprinus comatus YY-20," Applied Mechanics and Materials, vol. 138-19, pp. 1195-1201, 2012.

[10] S. Bao, Z. Teng, and S. Ding, "Heterologous expression and characterization of a novel laccase isoenzyme with dyes decolorization potential from Coprinus comatus," Molecular Biology Reports, vol. 40, no. 2, pp. 1927-1936, 2013.

[11] J. Sun, Q. J. Chen, M. J. Zhu, H. X. Wang, and G. Q. Zhang, "An extracellular laccase with antiproliferative activity from the sanghuang mushroom Inonotus baumii," Journal of Molecular Catalysis B: Enzymatic, vol. 99, pp. 20-25, 2014. 
[12] K.-S. Shin and Y.-J. Lee, "Purification and characterization of a new member of the laccase family from the white-rot basidiomycete Coriolus hirsutus," Archives of Biochemistry and Biophysics, vol. 384, no. 1, pp. 109-115, 2000.

[13] C. Gu, F. Zheng, L. Long, J. Wang, and S. Ding, "Engineering the expression and characterization of two novel laccase isoenzymes from Coprinus comatus in Pichia pastoris by fusing an additional ten amino acids tag at N-terminus," PLOS ONE, vol. 9, no. 4, Article ID e93912, 2014.

[14] H. Kellner, P. Luis, B. Schlitt, and F. Buscot, "Temporal changes in diversity and expression patterns of fungal laccase genes within the organic horizon of a brown forest soil," Soil Biology and Biochemistry, vol. 41, no. 7, pp. 1380-1389, 2009.

[15] J. Sun, Q.-J. Chen, Q.-Q. Cao et al., “A laccase with antiproliferative and HIV-I reverse transcriptase inhibitory activities from the mycorrhizal fungus Agaricus placomyces," Journal of Biomedicine and Biotechnology, vol. 2012, Article ID 736472, 8 pages, 2012.

[16] U. K. Laemmli and M. Favre, "Gel electrophoresis of proteins," Journal of Molecular Biology, vol. 80, pp. 575-599, 1973.

[17] D. D. Hu, R. Y. Zhang, G. Q. Zhang, H. X. Wang, and T. B. Ng, "A laccase with antiproliferative activity against tumor cells from an edible mushroom, white common Agrocybe cylindracea," Phytomedicine, vol. 18, no. 5, pp. 374-379, 2011.

[18] C. Eggert, U. Temp, and K.-E. L. Eriksson, "The ligninolytic system of the white rot fungus Pycnoporus cinnabarinus: purification and characterization of the laccase," Applied and Environmental Microbiology, vol. 62, no. 4, pp. 1151-1158, 1996.

[19] R. Bourbonnais, M. G. Paice, I. D. Reid, P. Lanthier, and M. Yaguchi, "Lignin oxidation by laccase isozymes from Trametes versicolorand role of the mediator 2,2' -azinobis(3ethylbenzthiazoline-6-sulfonate) in kraft lignin depolymerization," Applied and Environmental Microbiology, vol. 61, no. 5, pp. 1876-1880, 1995.

[20] P. M. Coll, J. M. Fernandez-Abalos, J. R. Villanueva, R. Santamaria, and P. Perez, "Purification and characterization of a phenoloxidase (laccase) from the lignin-degrading basidiomycete PM1 (CECT 2971)," Applied and Environmental Microbiology, vol. 59, no. 8, pp. 2607-2613, 1993.

[21] Y. Kojima, Y. Tsukuda, Y. Kawai et al., "Cloning, sequence analysis, and expression of ligninolytic phenoloxidase genes of the white-rot basidiomycete Coriolus hirsutus," The Journal of Biological Chemistry, vol. 265, no. 25, pp. 15224-15230, 1990.

[22] Y. Fukushima and T. K. Kirk, "Laccase component of the Ceriporiopsis subvermispora lignin-degrading system," Applied and Environmental Microbiology, vol. 61, no. 3, pp. 872-876, 1995.

[23] P. Giardina, V. Aurilia, R. Cannio et al., "The gene, protein and glycan structures of laccase from Pleurotus ostreatus," European Journal of Biochemistry, vol. 235, no. 3, pp. 508-515, 1996.

[24] S. Ben Younes and S. Sayadi, "Purification and characterization of a novel trimeric and thermotolerant laccase produced from the ascomycete Scytalidium thermophilum strain," Journal of Molecular Catalysis B: Enzymatic, vol. 73, no. 1-4, pp. 35-42, 2011.

[25] T. B. Ng, "Peptides and proteins from fungi", Peptides, vol. 25, no. 6, pp. 1055-1073, 2004.

[26] E. F. Fang, W. L. Pan, J. H. Wong, Y. S. Chan, X. J. Ye, and T. B. $\mathrm{Ng}$, "A new Phaseolus vulgaris lectin induces selective toxicity on human liver carcinoma Hep G2 cells," Archives of Toxicology, vol. 85, no. 12, pp. 1551-1563, 2011.
[27] G.-Q. Zhang, Y.-F. Wang, X.-Q. Zhang, T. B. Ng, and H.-X. Wang, "Purification and characterization of a novel laccase from the edible mushroom Clitocybe maxima," Process Biochemistry, vol. 45, no. 5, pp. 627-633, 2010.

[28] M. J. Zhu, F. Du, G. Q. Zhang, H. X. Wang, and T. B. $\mathrm{Ng}$, "Purification a laccase exhibiting dye decolorizing ability from an edible mushroom Russula virescens," International Biodeterioration and Biodegradation, vol. 82, pp. 33-39, 2013.

[29] H. X. Wang and T. B. Ng, "Purification of a laccase from fruiting bodies of the mushroom Pleurotus eryngii," Applied Microbiology and Biotechnology, vol. 69, no. 5, pp. 521-525, 2006.

[30] G.-Q. Zhang, Q.-J. Chen, H.-X. Wang, and T. B. Ng, "A laccase with inhibitory activity against HIV-1 reverse transcriptase from the mycorrhizal fungus Lepiota ventriosospora," Journal of Molecular Catalysis B: Enzymatic, vol. 85-86, pp. 31-36, 2013.

[31] H. X. Wang and T. B. Ng, "A new laccase from dried fruiting bodies of the monkey head mushroom Hericium erinaceum," Biochemical and Biophysical Research Communications, vol. 322, no. 1, pp. 17-21, 2004.

[32] G.-T. Tian, G.-Q. Zhang, H.-X. Wang, and T. B. Ng, "Purification and characterization of a novel laccase from the mushroom pleurotus nebrodensis," Acta Biochimica Polonica, vol. 59, no. 3, pp. 407-412, 2012.

[33] M. Li, G. Zhang, H. Wang, and T. Ng, "Purification and characterization of a laccase from the edible wild mushroom Tricholoma mongolicum," Journal of Microbiology and Biotechnology, vol. 20, no. 7, pp. 1069-1076, 2010.

[34] K.-L. Min, Y.-H. Kim, Y. W. Kim, H. S. Jung, and Y. C. Hah, "Characterization of a novel laccase produced by the woodrotting fungus Phellinus ribis," Archives of Biochemistry and Biophysics, vol. 392, no. 2, pp. 279-286, 2001.

[35] W. A. Edens, T. Q. Goins, D. Dooley, and J. M. Henson, "Purification and characterization of a secreted laccase of Gaeumannomyces graminis var. tritici," Applied and Environmental Microbiology, vol. 65, no. 7, pp. 3071-3074, 1999.

[36] G.-Q. Zhang, T. Tian, Y.-P. Liu, H.-X. Wang, and Q.-J. Chen, “A laccase with anti-proliferative activity against tumor cells from a white root fungus Abortiporus biennis," Process Biochemistry, vol. 46, no. 12, pp. 2336-2340, 2011.

[37] L. Q. Guo, S. X. Lin, X. B. Zheng, Z. R. Huang, and J. F. Lin, "Production, purification and characterization of a thermostable laccase from a tropical white-rot fungus," World Journal of Microbiology and Biotechnology, vol. 27, no. 3, pp. 731735, 2011. 

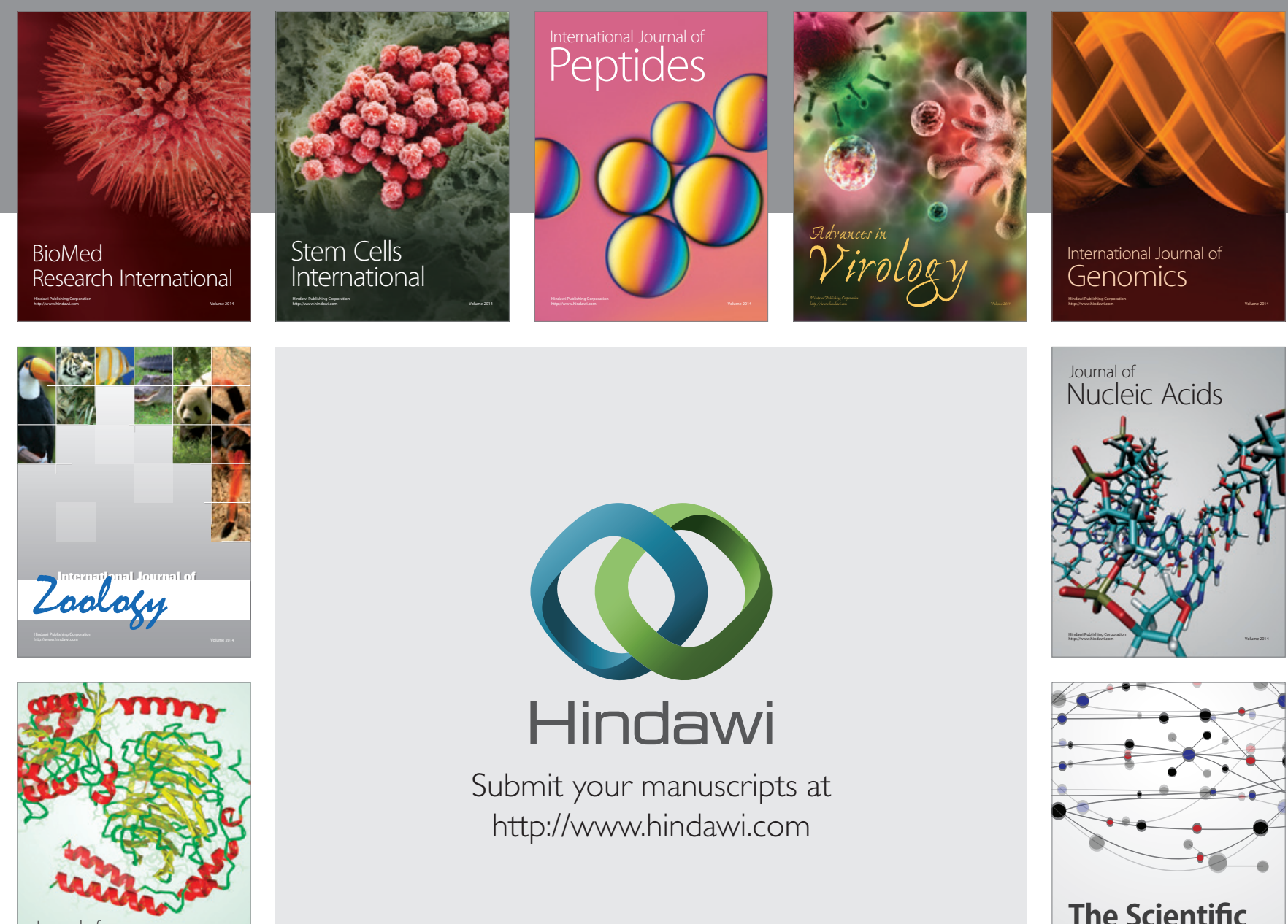

Submit your manuscripts at

http://www.hindawi.com

Journal of
Signal Transduction
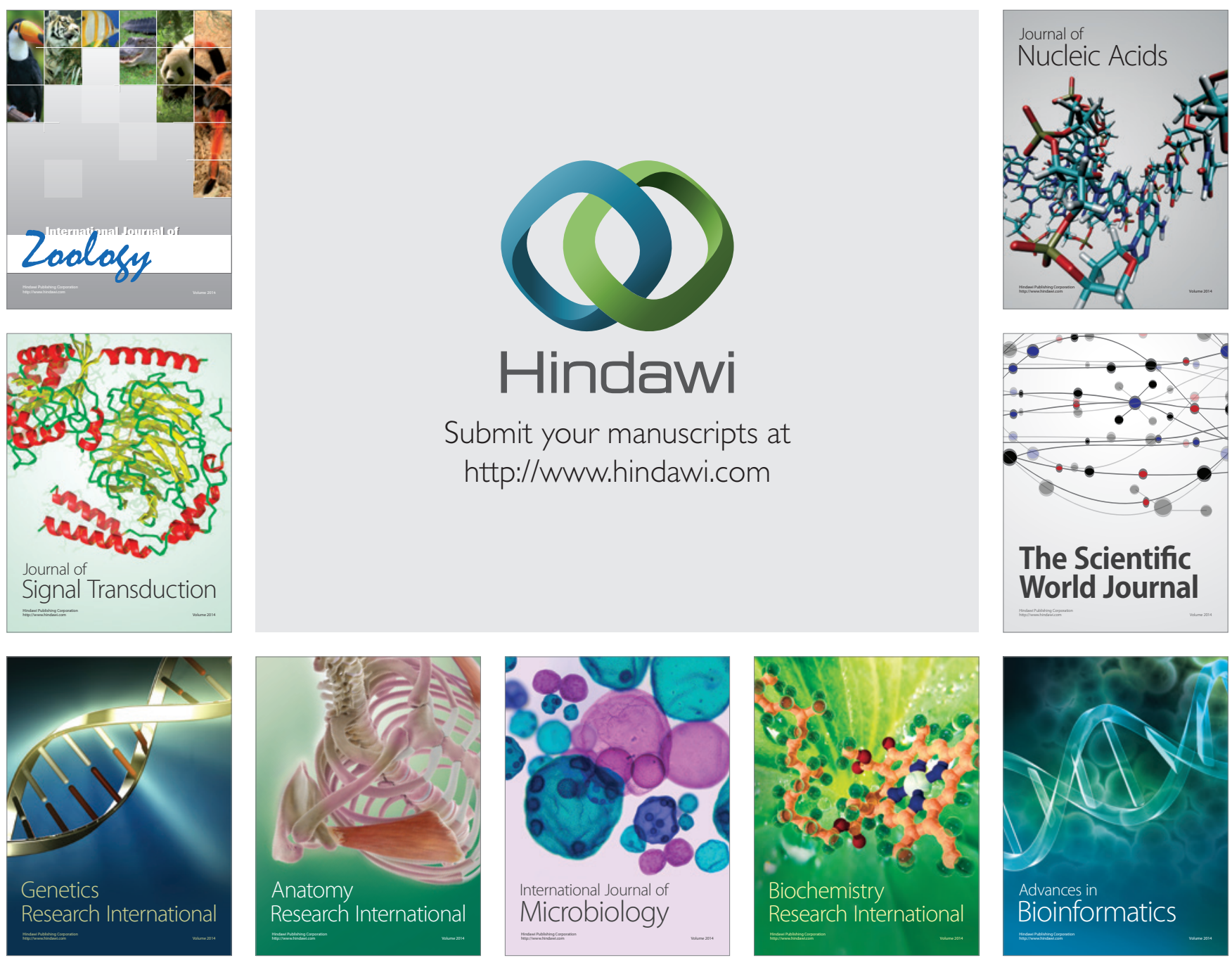

The Scientific World Journal
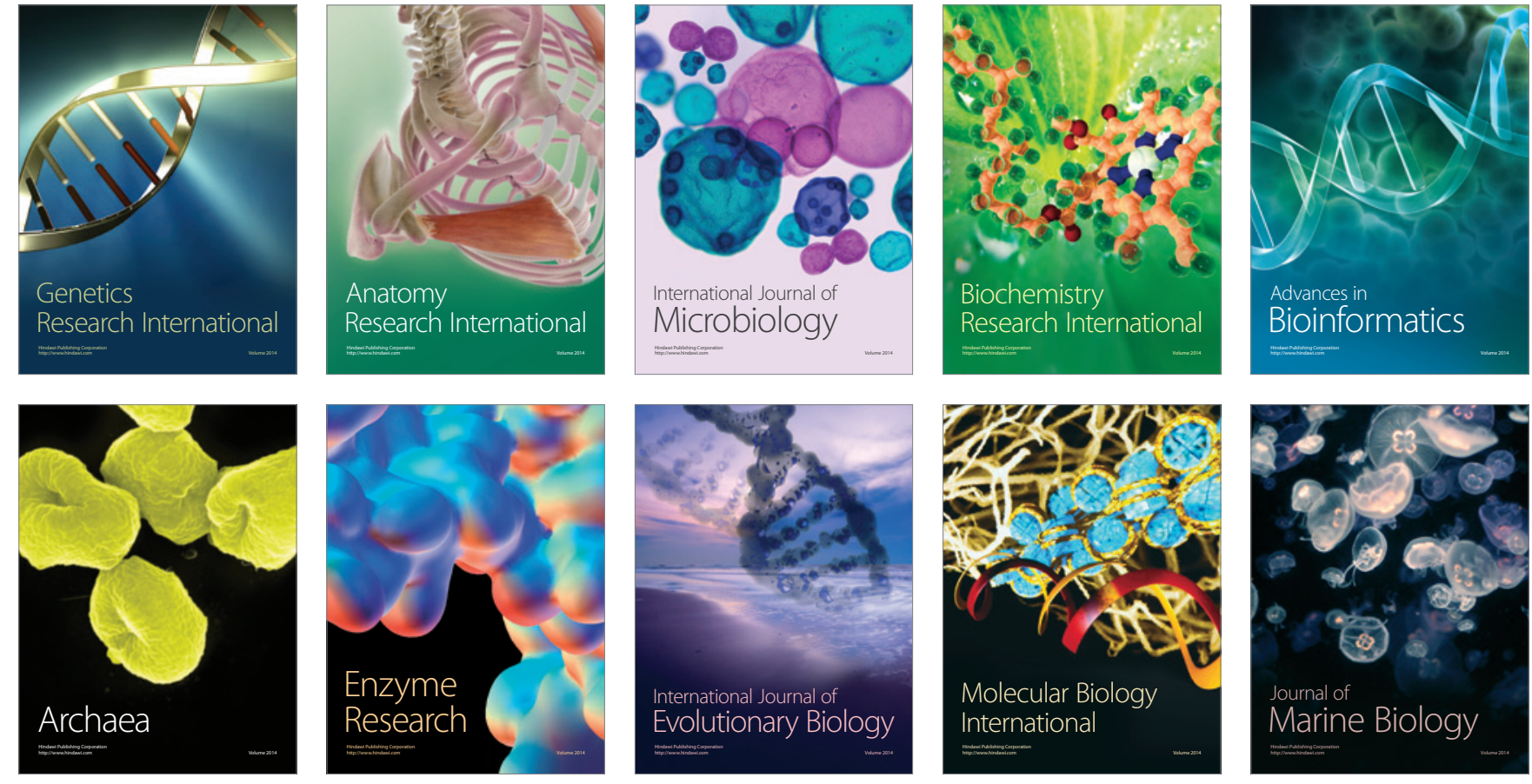